一論文—

（日本化学会誌，1988，(7), p. 1059 1064)

(C) 1988 The Chemical Society of Japan

\title{
化学修飾シリカゲルを触媒とする アルキルベンゼンの塩素化反応
}

\author{
（1987 年 12 月 28 日受理）
}

小西久俊*・市橋裕司・今井雅明・岡野多門・木地実夫

有機官能基を化学結合により固定化して調製した修飾シリカゲルを触媒とする，アルキルベンゼンの 核塩素化反応について検討した。生成物分布およびアルキルベンゼン類, ハロベンゼン類の相対反応性 から, シリカゲル触媒による塩素化反応は, 典型的な求電子置換反応であり, 活性な求電子種はシリカ ゲル表面に存在していると考兄られる。表面修飾基の違いにより，p-グロ体とo-ク口ロ体の生成比 が変化し, 四塩化炭素中でのクメンの塩素化では, ジニトロベンズアミド誘導体を結合させたシリカゲ ル (SIL-17, 18) は，無修飾シリカゲルにくらべてパラ位選択性（p/o 比）が 4 倍以上向上した。表面 修飾の効果は非極性溶媒中で顕著にみられ，固定化された有機官能基と基質，および／あるいは試薬と の静電的な相互作用により, パラ位選択性が向上したと推測された。また, 無修飾シリカゲルの触媒活 性は急激に低下するのに対し，選択性の優れた修飾シリカゲルでは，活性低下がきわめて小さく，くり 返し再使用が可能であった。

\section{1 緒言}

有機化合物をシリカゲルやアルミナなどの無機固体表面に吸着 した状態で反応させると，選択性が均一系反応の場合とは異なる 結果が得られることがあり, 合成化学的な観点から関心がもたれ ている(1) たとえば, シリカゲルに吸着した酢酸エステルのオ ゾン酸化 ${ }^{4) 5}$ ，アルミナに吸着したジカルボン酸のモノェステル 化 ${ }^{6)}$ な゙，無機固体を利用した反応により，特異な選択性が達成 されている。このような基質は極性の高い官能基の部位で固体表 面に吸着し, その結果, 固体表面上の基質分子は特定の方向性を もち，溶液中での反応とは異なる選択性が得られたものとみられ る。

一方, 四塩化炭素中での鎖状カルボン酸の塩素化反応に打いて は, アルミナの添加により, 位膡選択性が明らかに変化すること が認められたが，溶液中に存在する基質も塩素化されたために十 分な選択性は得られていないっ。このように反応系が固-液二相系

鳥取大学工学部資源㡒環化学科, 680 鳥取市湖山町

1) A. Makillop, D.W. Young, Synthesis 1979, 401, 481.

2) 北條 卓, 増田良一, 有合化, 37, 557, 689(1979).

3) 日本化学会編, 安藤喬志, 市原潤子, 花房昭静, “化学総 説 No. 47, 有機合成反応をいかに制御するか”，学会出版 センター (1985) p. 166.

4) Z. Cohen, E. Keinan, Y. Mazur, A. Ulman, J. Org. Chem., 41, 2651(1976).

5) A. L. J. Beckwith, T. Duong, J. Chem. Soc., Chem. Commun., 1978, 413.

6) H. Ogawa, T. Chihara, K. Taya, J. Am. Chem. Soc., 107, 1365(1985).

7) N. C. Deno, R. Fishbein, C. Pierson, ibid., 92, 1451 (1970).
の場合は，液相中での反応も起こりやすいために，無機固体界面 の影響が現わ机にくい。しかし，基質と活性な試薬の接近が固一 液の界面でのみ起こるようにできれば，高い選択性が発現される のではないかと期待された。界面が扣るな反応場となる系とし て，無機固体が触媒として作用し，活性化された試薬は固体表面 にのみ存在し，ここへ接近する基質たけが反応関与する系が考 えられる。著者らはこれらの条件を満たす系として、シリカゲル が触媒作用を示す反応を取り上げた。

シリカゲルを触媒とする芳香族炭化水素の核塩素化反応は，種 々の塩菜化試楽について検討されて拈り ${ }^{8)}$ 10), アルキルベンゼン との反応では， 0 -クロ口体と $p$-クロロ体が主生成物となる典型 的な求電子置換反応で，バラ体の選択率が，Lewis 酸を触媒とす る均一系の場合にくらべてやや高いことから, 求電子種が固体触 媒表面上に，かさ高い状態となって存在していることが示唆され ていだ11。

したがって, シリカゲル表面に活性な求電子種が存在し，ここ に接近する基質分子の向きが制御できれば，基質分子の特定の部 位に求電子の攻撃が起こりやすくなり, 高度な位置選択性を得る ことが可能となると期待された。さきに，著者らはこの様な観点 から基質分子と静電的な相互作用をしらる有機官能基を固定化し たシリカゲルを調製し，これを触媒とするアルキルベンゼン類の 塩素化を行ない，パラ位選択性が大きく向上することを報告し

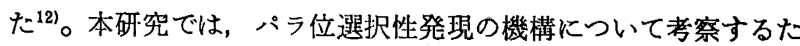

8) C. Yaroslavsky, Tetrahedron Lett., 1974, 3395.

9) M. Hojo, R. Masuda, Synth. Commun., 5, 169(1975).

10) K. Smith, M. Batters, W. E. Paget, B. Nay, Synthesis, 1985, 1155.

11) Th. M. Wortel, D. Oudijn, C. J. Vleugel, D. P. Roelofsen, H. van Bekkum, J. Catal., 60, 110(1979). 
めに，種々の官能基を固定化したシリカゲルを調製し，置換基効 果, 触媒作用の経時変化, 溶媒効果について検討した。

\section{2 実験}

\section{1 分 析}

生成物の分析は, 水素炎検出器を備えた柳本 G-180 型ガスク ロマトグラフを使用し, 長さ $3 \mathrm{~m}$, 径 $3 \mathrm{~mm}$ のガラスカラムで, 夜相/担体として, Silicone DC-560 (10\%)/Chromosorb W, Silicone OV-17(2\%)/Chromosorb W, PEG $20 \mathrm{M}(25 \%) /$ Shimalite, 4, 4'-azoxyanisole(10\%)/Uniport B を用いて行なった。元 素分析は京都大学微量分析センターに依頼した。

\section{2 シリカゲルの前処理}

シリカゲル (Wakogel C-300) $500 \mathrm{~g}$ に濃塩酸 $(1.8 l$ )を加光, 混合物を 6 時間 $70^{\circ} \mathrm{C}$ に加熱した。シリカゲルを汇過により集 め, 塩化物イオンが汇液中に認められなくなるまで水洗した。減 圧下, $80^{\circ} \mathrm{C}$ で恒量に達するまで乾燥し, 密閉容器中に保存した。

\section{3 シリカゲルとトリアルコキシシラン誘導体の反応}

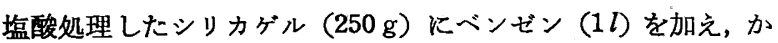
きまぜながら加熱還流し, Dean-Stark トラップを用いて少量の 水を共沸蒸留により除去した。ここへトリアルコキシシラン誘導 体 $(0.5 \mathrm{~mol})$ を加え, 混合物を 48 時間加熱還流した。シリカゲ ルを Soxhlet 抽出装固に移し, 熱ベンゼン可溶部を 24 時間抽出 除去後, 減圧下, $80^{\circ} \mathrm{C}$ で恒量に達するまで乾燥した。

\section{$2.43-$ 3-アノプロピル化シリカゲルのベンソイル化反応}

(3-アミノプロピル)トリエトキシシランを用いて調製した 3フミノプロピル化シリカゲル $(20 \mathrm{~g})$ Kベンゼン $300 \mathrm{ml}$ を加光， 共沸蒸留により少量の水を除いた。これに塩化ベンゾイル誘導体 $(40 \mathrm{mmol})$ およびトリェチルアミン $(40 \mathrm{mmol})$ を加え, 24 時間 加熱還流した。シリカゲルは Soxhlet 抽出装置を用いて熱ベンゼ ン可溶部を 24 時間抽出除去し, メタノール, 水で洗浄後, $80^{\circ} \mathrm{C}$ で佰量に達するまで減王乾燥した。

\section{5 シリカゲル触媒によるアルキルベンゼン類の塩素化} 塩素化反応は暗条件下，つぎの二通りの方法で行なった。 条件 A（四塩化炭素中での塩素化）

基質 $(5 \mathrm{mmol})$ と触媒 $(0.5 \mathrm{~g})$ を $100 \mathrm{ml}$ のなす形フラスコに いれ，さらに塩素 $(5 \mathrm{mmol}$ ) を含む四塩化炭素溶液 (約 $20 \mathrm{ml}$ ) を加え密閉した。この容器をロータリーエバポレーターの駆動部 を利用して穏やかに 1 時間回転させた。触媒を沪別した後，有機 層を炭酸水素ナトリウム水溶液で洗浄し，ガスクロマトグラフィ 一により分析した。

条件 B（無溶媒塩素化）

かきまぜ機および気体の導入口，排出口をつけた $200 \mathrm{~m} l$ 三つ

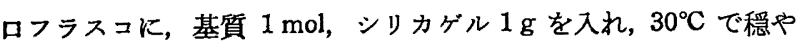
かにかきまぜながら塩素ガスを $1 \mathrm{~mol} / \mathrm{h}$ の割合で導入した。所定 量の塩素を導入した後, さらに 10 分間かきまぜ, 触媒をデカン テーションで除き，条件 Aと同様に処理して分析した。

\section{3 結 果と考察}

\section{1 シリカゲルの表面修飾}

触媒としてカラムクロマトグラフィー用のシリカゲル（Wako-

12) H. Konishi, K. Yokota, Y. Ichihashi, T. Okano, J. Kiji, Chem. Lett., 1980, 1423.
$\left(\mathrm{SiO}_{2}\right)$

$\underset{\text { Benzene }}{\stackrel{\left(\mathrm{C}_{2} \mathrm{H}_{5} \mathrm{O}\right)_{3} \mathrm{SiCH}_{2} \mathrm{CH}_{2} \mathrm{CH}_{2} \mathrm{NH}_{2}}{\longrightarrow}}\left(\mathrm{SiO}_{2}\right) \equiv \mathrm{SiCH}_{2} \mathrm{CH}_{2} \mathrm{CH}_{2} \mathrm{NH}_{2}$

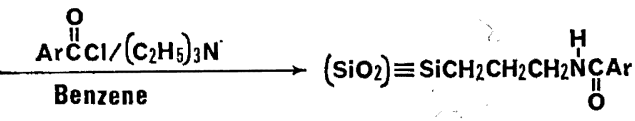

Scheme 1 Preparation of chemically-modified silica gels

gel C-300)を使用した。シリカゲルは，表面ヒドロキシル基密度 を一定にするために濃塩酸で処理し ${ }^{13)}$ ，塩化物イオンが検出され なくなるまで洗浄後，減圧下 $80^{\circ} \mathrm{C}$ で恒量に達するまで乾燥し た。さらに反応にさきだって，表面に吸着した水をベンゼンとの 共沸蒸留により除去した。これらの操作は, シリカダルの表面に 官能基を均一に，また単分子層状に結合させようとして行なった ものであるが，この点については後に考察する。

シリカゲル表面への官能基の固定は図式 1 亿示すように行なっ た。表 1 とここで使用した修飾シリカゲルのコード番号，その表 面に固定化された官能基の構造，および元素分析值から求めた担 体シリカゲル $1 \mathrm{~g}$ あたりの官能基の結合量（ミリ当量）を示す。

修飾シリカゲル SIL-1〜－6，はトリアルコキシシラン誘導体と シリカゲルの反応により調製した。修飾シリカゲル SIL-7〜20 は，対応するアミノ基を含む修飾シリカゲルから調製した。アミ ノ基の反応は過剩の試薬を用いても完全には進まず，未反応のア ミノ基が存在するが，ここでは反応が完全に進行するものとして 構造式を示す。本実験のベンゾイル化の条件では, アミノ基に対 して 2 倍量の試楽を使用した場合， $10 \%$ 弱のアミノ基が末反応 のまま残っているものとみられる。

シリカゲル単位重量あたりの結合量は，いずれの場合も 0.9 な いし 1.2 ミリ当量 $/ \mathrm{g}$ と, 注注同程度で大差は認められない。官 能基の表面密度を, 使用したシリカゲルの比表面積 $\left(330 \mathrm{~m}^{2} / \mathrm{g}\right)$ を基にして計算すると，1.5 2.0 個/ $\mathrm{nm}^{2}$ となる。なお，この值 は水面上に展開したステフリン酸単分子膜の密度 $\left(5\right.$ 個 $\left./ \mathrm{nm}^{2}\right)$ の 約 3 分の 1 である ${ }^{14) 。}$

SIL-3 捄よび-12 は, 3-アミノプロピル化の段階でエトキシル 基に対して等量の水を添加したもので，一部の修飾基はオリゴマ 一となってシリカゲル表面に結合し ${ }^{15)}$ ，その結果，結合量が增加 しているとみられる。

\section{2 シリカゲルの触媒作用}

塩素化反応に扑けるシリカゲルの触媒作用については，これま で詳細には検討されていない。まず最初に，本研究に関連したい くつかの事項について検討した。

はじめに，反応がシリカゲル表面でのみ進行するるのが゙うか を検討するために，きわめてかさ高い基質であるポリスチレンの 塩素化を行なった。ポリスチレン（重合度 1000）塩化アンチモ ン(III)触媒の存在下，四塩化炭素溶液中て塩素により容易に塩素 化されるが16)，シリカゲル触媒では注とんど塩素化されなかっ だ。クメンが塩化アンチモン(III)、シリカゲルいずれを触媒とし

13) J.S. Fritz, J. N. King, Anal. Chem., 48, 570(1976).

14) I. Langmuir, J. Am. Chem. Soc., 39, 1848(1917).

15) K. K. Unger, N. Becker, P. Roumeliotis, J. Chromatogr., 125, 115(1976).

16) J. Kiji, H. Konishi, T. Okano, S. Sugino, A. Iwasa, Makromol. Chem., Rapid Commun., 6, 49(1985). 
日化, 1988, No.7 小西・市橋・今井・岡野・木地：化学修飾シリカゲルを触媒とするアルキルベンゼンの塩素化反応 1061

Table 1 Chemically-modified silica gels

\begin{tabular}{|c|c|c|c|c|c|}
\hline \multirow{2}{*}{$\begin{array}{c}\text { Code } \\
\text { number }\end{array}$} & \multirow{2}{*}{ Anchoring group } & \multicolumn{3}{|c|}{ Elemental analysis $(\%)$} & \multirow{2}{*}{$\begin{array}{c}\text { Anchored } \\
\text { functional } \\
\text { group } \\
\left(\mathrm{meq} / \mathrm{g}-\mathrm{SiO}_{2}\right)\end{array}$} \\
\hline & & $\mathrm{C}$ & $\mathrm{H}$ & $\mathrm{N}$ & \\
\hline SIL-1 & $-\left(\mathrm{CH}_{2}\right)_{7} \mathrm{CH}_{3}$ & - & - & - & - \\
\hline SIL-2 & $-\left(\mathrm{CH}_{2}\right)_{3} \mathrm{NH}_{2}$ & 4.01 & 1.16 & 1.25 & 0.97 \\
\hline SIL-3 & $-\left(\mathrm{CH}_{2}\right)_{3} \mathrm{NH}_{2}$ (oligomer) & - & - & 4.57 & 4.54 \\
\hline SIL-4 & $-\left(\mathrm{CH}_{2}\right)_{3} \mathrm{NHCH}_{3}$ & 6.22 & 1.55 & 1.55 & 1. 24 \\
\hline SIL-5 & $-\left(\mathrm{CH}_{2}\right)_{3} \mathrm{NH}\left(\mathrm{CH}_{2}\right)_{2} \mathrm{NH}_{2}$ & - & - & 3.09 & 1.29 \\
\hline SIL-6 & $-\left(\mathrm{CH}_{2}\right)_{3} \mathrm{NH}\left[\left(\mathrm{CH}_{2}\right)_{2} \mathrm{NH}\right]_{2} \mathrm{H}$ & - & - & 4.03 & 1.15 \\
\hline SIL-7 & $-\left(\mathrm{CH}_{2}\right)_{3} \mathrm{NHC}_{6} \mathrm{H}_{3}\left(\mathrm{NO}_{2}\right)_{2}-2,4$ & - & - & - & - \\
\hline SIL-8 & $-\left(\mathrm{CH}_{2}\right)_{3} \mathrm{NHCH}_{2} \mathrm{C}_{6} \mathrm{H}_{3}\left(\mathrm{NO}_{2}\right)_{2}-2,4$ & - & - & - & - \\
\hline SIL-9 & $-\left(\mathrm{CH}_{2}\right)_{3} \mathrm{NHSO}_{2} \mathrm{C}_{6} \mathrm{H}_{3}\left(\mathrm{NO}_{2}\right)_{2}-2,4$ & - & - & - & - \\
\hline SIL-10 & $-\left(\mathrm{CH}_{2}\right)_{3} \mathrm{NHCOC} \mathrm{H}_{3}\left(\mathrm{NO}_{2}\right)_{2}-2,4$ & 10.30 & 1.20 & 3.24 & 1.05 \\
\hline SIL-11 & $-\left(\mathrm{CH}_{2}\right)_{3} \mathrm{NHCOC}_{6} \mathrm{H}_{3}\left(\mathrm{NO}_{2}\right)_{2}-3,5$ & 9.16 & 1.21 & 2.96 & 0.88 \\
\hline SIL-12 & $-\left(\mathrm{CH}_{2}\right)_{3} \mathrm{NHCOC}_{6} \mathrm{H}_{3}\left(\mathrm{NO}_{2}\right)_{2}-3,5$ (oligomer) & - & - & 5.47 & 2.05 \\
\hline SIL-13 & $-\left(\mathrm{CH}_{2}\right)_{3} \mathrm{NHCOC} \mathrm{H}_{6} \mathrm{H}_{3}\left(\mathrm{NO}_{2}\right)_{2}-3,4$ & 9. 90 & 1.17 & 3.25 & 0.99 \\
\hline SIL-14 & $-\left(\mathrm{CH}_{2}^{\prime}\right)_{8} \mathrm{NHCOC}_{6} \mathrm{H}_{4} \mathrm{NO}_{2}-2$ & 10.95 & 1.40 & 2.31 & 1.02 \\
\hline SIL-15 & $-\left(\mathrm{CH}_{2}\right)_{3} \mathrm{NHCOC}_{6} \mathrm{H}_{4} \mathrm{NO}_{2}-3$ & 11.00 & 1,31 & 2.49 & 1.12 \\
\hline SIL-16 & $-\left(\mathrm{CH}_{2}\right)_{3} \mathrm{NHCOC}_{6} \mathrm{H}_{4} \mathrm{NO}_{2}-4$ & 10.84 & 1.31 & 2.22 & 0.97 \\
\hline SIL-17 & $-\left(\mathrm{CH}_{2}\right)_{3} \mathrm{~N}\left(\mathrm{CH}_{3}\right) \mathrm{COC}_{6} \mathrm{H}_{3}\left(\mathrm{NO}_{2}\right)_{2}-3,5$ & 11.97 & 1. 49 & 3.54 & 1. 12 \\
\hline SIL-18 & $-\left(\mathrm{CH}_{2}\right)_{3} \mathrm{~N}\left(\mathrm{CH}_{3}\right) \mathrm{COC}_{6} \mathrm{H}_{3}\left(\mathrm{NO}_{2}\right)_{2}-2,4$ & 12.54 & 1. 47 & 3. 71 & 1. 19 \\
\hline SIL-19 & $-\left(\mathrm{CH}_{2}\right)_{3} \mathrm{NH}\left(\mathrm{CH}_{2}\right)_{2} \mathrm{NHCOC}_{6} \mathrm{H}_{3}\left(\mathrm{NO}_{2}\right)_{2}-3,5$ & - & - & 5. 78 & 1.07 \\
\hline SIL-20 & $-\left(\mathrm{CH}_{2}\right)_{3} \mathrm{NH}\left[\left(\mathrm{CH}_{2}\right)_{2} \mathrm{NH}\right]_{2} \mathrm{COC}_{6} \mathrm{H}_{3}\left(\mathrm{NO}_{2}\right)_{2}-3,5$ & - & - & 6.76 & 0.90 \\
\hline
\end{tabular}

た場合も，速やかに塩素化されることを考慮すると，ポリスチレ ンの反応性の低さは，そのかさ高さに基づくと思われる。すなわ ち,シリカゲルを触媒とした場合には，塩素化の活性種がシリカ ゲル表面上に存在しており，ここに接近しにくいかさ高い基質 は, 反応性が低いと考えられる。したがって，塩素化の活性種は 溶液中には存在せず, アルキルベンゼン類の塩素化反応は, シリ カゲル表面を反応場として進行するものと解釈される。

シリカゲル触媒による塩素分子のイオン的な活性化には, 表面 ヒドロキシル基の存在が必要である17)。本実験で使用したシリカ ゲルは, 高温での乾燥処理をしていないので, 表面ヒドロキシル 基が多量に存在すると推定される。実際，この無修飾シリカゲル は, アルキルベンゼンの液相塩素化では高活珄を示したが，これ をトリメチルクロロシランで処理すると, 塩素化の活性はいちじ るしく低下した。これは大部分の表面ヒドロキシル基がトリメチ ルシリル化され，消失したためと解釈される。一方，トリエトキ シシラン誘導体で処理したシリカゲルは，塩素化反応に拈いて触 媒活性を示した。これはトリエトキシシラン誘導体が, シリカゲ ル表面上のすべてのヒドロキシル基とは反応できない結果と思わ れる ${ }^{18)}$ 。修䬣基密度と無定形シリカゲルの表面ヒドロキシル基密 度の理論最大值 $\left(5 \sim 7 \text { 個 } / \mathrm{nm}^{2}\right)^{19)}$ から推定すると, 半数近くの表 面ヒドロキシル基が残存し，触媒作用を示すのに十分な量である と思われる。

\section{3 修飾シリカゲル触媒による四塩化炭素中でのクメンの塩 素化}

表面修飾の効果がもっとも顕著にみられた四塩化炭素中での塩

17) T. Huizinga, J. J. F. Scholten, Th. M. Wortel, H. van Bekkum, Tetrahedron Lett., 1980, 3809.

18) L. L. Murrel, "Advanced Materials in Catalysis", Ed by J.J.Burton, R. L. Garten, Academic Press, New York (1977) Chap. VIII.

19) H.P. Boehm, Adv. Catalysis, 16, 179(1966).
素化の結果から，修飾基の構造と反応の位值選択性の関連につい て考察した。クメンの塩素化の結果を表 2 に示す。この塩素化条 件では, $p$-ク口口体とoーク口ロ体を主とする核塩素化物が主生 成物であり，多塩素化物および側鎖塩素化物はほとんど生成しな かった。また $m$ ークロ口体は，いずれの実験においても $1 \%$ 程度 で, 大きな変化はみられなかったので, 位置選択性をパラ位眉換 体とオルト位眉換体の生成比（p/o 比）で評価した。また, 触媒 活珄は反応率 (Conv\%) で行なった。

無修飾シリカゲルを触媒とした場合の $p / 0$ 比は 1.16 であり,

Table 2 Chlorination of cumene in carbon tetrachloride catalyzed by chemically-modified silica gels ${ }^{a}$

\begin{tabular}{lcc} 
Catalyst & Conv. $/ \%$ & $p / o$ \\
\hline $\mathrm{SiO}_{2}$ (unmodified) & 75.0 & 1.16 \\
$\mathrm{SiO}_{2}$ (TMS treated) & 0.0 & - \\
$\mathrm{SIL-1}$ & 73.2 & 1.24 \\
$\mathrm{SIL}-2$ & 61.6 & 1.43 \\
$\mathrm{SIL}-7$ & 52.1 & 1.78 \\
$\mathrm{SIL}-8$ & 49.9 & 2.09 \\
$\mathrm{SIL}-9$ & 43.6 & 2.00 \\
$\mathrm{SIL}-10$ & 41.2 & 3.30 \\
$\mathrm{SIL}-11$ & 58.0 & 3.84 \\
$\mathrm{SIL}-12$ & 2.6 & 1.52 \\
$\mathrm{SIL}-13$ & 63.6 & 2.81 \\
$\mathrm{SIL}-14$ & 2.6 & 1.26 \\
$\mathrm{SIL}-15$ & 5.6 & 1.53 \\
SIL-16 & 40.3 & 2.82 \\
SIL-17 & 46.2 & 4.38 \\
SIL-18 & 13.6 & 4.82 \\
SIL-19 & 78.7 & 3.38 \\
SIL-20 & 18.6 & 4.06
\end{tabular}

a) Conditions; cumene $5 \mathrm{mmol}, \mathrm{Cl}_{2} 5 \mathrm{mmol}$, silica gel $0.5 \mathrm{~g}$, solvent $15 \mathrm{ml}, 30^{\circ} \mathrm{C}, 1 \mathrm{~h}$. 
直鎖アルキル基 (SIL-1) あるいは3-アミノプロピル基 (SIL-2) の固定化では，p/o 比の向上は小さかった。

3-アミノプロピル化シリカゲルにニトロベンゼン誘導体を種々 の方法で結合させたシリカゲルでは, 明らかにパラ位選択性の向 上が認められた。2,4-ジニトロベンゼン誘導体（SIL-7〜-10）の なかでは，とくにベンズアミド誘導体が高いp/o 比を示した。

3 種のジニトロペンズアミド誘導体および 4-ニドロベンズア ミド誘導体では，活性，選択性に関してともに良好な結果を得た が，2-ニトロおよび，3-ニト口誘導体はいずれる活性がきわめて 低く，位置選択性もみられなかった。これらの修飾シリカゲルの 官能基含有量には違いは認められず，触媒活性の差がどの様な原 因に基づくものか不明である。

3-(2-アミノェチルフミノ)プロピル化および 3-(2-(2-アミ) エチルフミノ)エチルアミノ)プロピル化シリカゲル (SIL-5, -6) から調製したニトロベンズアミド誘導体 (SIL-19, -20) む，優れ た位膡選択性を示した。これらの修飾シリカゲルで性，シリカゲ ル表面から比較的離れた位固に，ベンズフミド基が存在している むのとみられ, シリカゲル表面とアミド基の位置関係は重要な要 因ではない。

シリカゲル表面上に修飾基が存在することにより，基質の側鎖 との間に立体的な反発が生し，その結果，パラ位選択性が增加す るとも考えられる。しかし, 本実験の結果から，修飾基の構造と パラ位選択性について明らかな関連性は認められなかったので, このよらな単純な立体的な反発だけでは，位直選択性の向上を説 明することはできない。

あるいは，修飾基に含まれるアミド基の水素と塩素の反応によ り $N$-クロロアミドが生成し，これが選択性の高い塩素化試薬と なる可能性がある。しかし，3-メチルアミノプロピル基を有する シリカゲルから調製した SIL-17 には, アミド基水素はないが, 選択性，活性ともにもっとも優れた触媒の一つであり，アミド基 を多く含むシリカゲルが，必ずしもよい結果を与えないことから む，修飾基が関与した選択性の高い塩素化試薬の生成はないもの と思われる。

\section{4 ハララ位選択性におよぼす溶媒効果}

修飾基と基質との相互作用について知見を得るために，各種の 溶媒中でクメンの塩素化を行なった（表 3 ）。

Table 3 Solvent effect on the plo ratio of silica gel-catalyzed chlorination of cumene ${ }^{a)}$

\begin{tabular}{lcc}
\multirow{2}{*}{ Solvent } & \multicolumn{2}{c}{$p / 0$} \\
\cline { 2 - 3 } & $\mathrm{SiO}_{2}$ & $\mathrm{SIL}-11$ \\
\hline $\mathrm{CCl}_{4}$ & 1.16 & 3.84 \\
$\mathrm{CHCl}_{3}$ & 1.35 & 3.12 \\
$\mathrm{ClCH}_{2} \mathrm{CH}_{2} \mathrm{Cl}$ & 1.36 & 2.95 \\
$\mathrm{Cumene}^{b)}$ & 1.18 & 2.53 \\
$\mathrm{C}_{6} \mathrm{H}_{5} \mathrm{NO}_{2}$ & 1.20 & 1.70 \\
$\mathrm{CH}_{3} \mathrm{CN}^{2}$ & 2.03 & 2.10 \\
$\mathrm{CH}_{3} \mathrm{NO}_{2}$ & 2.10 & 2.18
\end{tabular}

a) Conditions ; cumene $5 \mathrm{mmol}, \mathrm{Cl}_{2} 5 \mathrm{mmol}$, silica gel $0.5 \mathrm{~g}$, solvent $15 \mathrm{ml}, 30^{\circ} \mathrm{C}, 1 \mathrm{~h}$.

b) Used as solvent $15 \mathrm{ml}$.

20) L. M. Stock, A. Himoe, Tetrahedron Lett., 1960, (13) 9.
SIL-11 を触媒とした場合，四塩化炭素中での $p / 0$ 比がもっと も高く，アセトニトリルやニトロメタン中では，無溶媒条件より も p/o 比は低下した。これに対して，無修䬣シリカゲルでは， 四塩化炭素中で $p / 0$ 比がもっとも低くなった。いずれの触媒も， アセトニトリルとニトロメタン中では，ほぼ同じ結果が得られた が, これは溶媒和した求電子種による塩素化が，主反応になった ためと考学られる20)。

修飾シリカゲルが, 四塩化炭素中でもっとも高いp/o 比を示し たことから, 修飾基と基質および求電子試薬との静電的な相互作 用が，パラ位選択性発現に重要な役割を果しているのではないか と示唆される。すなわち, 四塩化炭素中では, ニト口基やアミド 基のような極性の高い官能基と，イオン性の求電子種と静電的な 結合，あるいは，修飾基中の電子受容性の芳香環と，基質との電 荷移動錯体形成などの静電的な相互作用が強く働き，反応の位置 選択性に影響をおよぼしたものとみられる。一方：アセトニトリ ルなどの極性の高い溶媒中では，このよらな静電的な相互作用は 十分作用せず，表面修飾の効果が現われないのではないかと考え られる。

\section{5 置換ベンゼン類の塩素化}

4 種のアルキルベンゼンと 3 種のハロベンゼンについて, SIL11 および塩化アンチモン(II)を触媒とする塩素化を, 四塩化炭 素中で行ない，䣫酸中での無触媒塩素化 ${ }^{21)}$ と比較した。今回の条 件では, 酢酸中での塩素化にくらべて, 修飾シリカゲルを触媒と する塩素化は, 塩化アンチモン(II) 触媒の場合と同じくらい速や かに進行した。p/o 比抢よび競争反応におけるモノクロロ体の生 成比から求めた， ベンゼンを基準とする相対反応速度を，表 4 に 示す。

p/o 比は塩化フンチモン(III) と酢酸の系では，ほぼ同じくらい であり，SIL-11 ではこれらの系にくらべて，t-ブチルベンゼンを 除き，1.5ないし 2 倍程度の值となった。また，基質選択性は， 塩化アンチモン(III)>酢酸>SIL-11 の順に減少した。基質選択 性の低いSIL-11 が，もっとも優れた位置選択性を示したことは 興味潹い。

修飾シリカゲル触媒による $t$-ブチルベンゼンの塩麦化では, p/o 比がとくに大きく，置換基のかさ高さに基つくく影響が現われ たものとみられ，置換基とシリカゲル表面の官能基との立体的な 相互作用が寄与した結果と考乓られる。

\section{6 触媒作用の経時変化および触媒のくり返し使用}

実用的な钼点から，無溶媒条件での触媒作用の経時変化，拉よ び促媒のくり返し使用について検討した。塩素化は，基質 1 モル あたり $1 \mathrm{~g}$ の触媒を用い，塩素を連続的に反応系へ導入すること により行なった。

無修飾シリカゲル（塩酸処理）と，3種の修飾シリカゲルによ るクメンの塩素化の結果を図 1 に示す。基質の变換率から触媒活 性の経時变化を判断すると，反応初期には，無修飾シリカゲルの 活性がもっとも高いが，20 分後頃から徐々に低下し，40 分後に はほとんど塩素化は起こらなくなった。反応後回収したシリカゲ ルの外钼には，変化が認められなかった。これを風乾後再使用し たところ，触煤活性がきわめて低かった。この活性化には熱王水 での処理が必要であった。なお，無修䬣シリカゲルによる塩絜化

21) L. M. Stock, F.W. Baker, J. Am. Chem. Soc., 84, 1661(1962). 
Table 4 Relative rates ${ }^{a)}$ and $p / 0$ ratios $^{b)}$ for chlorination of monosubstituted benzenes

\begin{tabular}{|c|c|c|c|c|c|c|}
\hline \multirow{2}{*}{ Substituent } & \multicolumn{2}{|c|}{$\mathrm{SIL}-11 / \mathrm{CCl}_{4}$} & \multicolumn{2}{|c|}{$\mathrm{SbCl}_{3} / \mathrm{CCl}_{4}$} & \multicolumn{2}{|c|}{$\mathrm{CH}_{3} \mathrm{COOH}^{\mathrm{c})}$} \\
\hline & $k_{\mathrm{rel}}$ & $p / o$ & $k_{\mathrm{rel}}$ & $p / o$ & $k_{\mathrm{rel}}$ & $p / o$ \\
\hline $\mathrm{CH}_{3}$ & $1.3 \times 10^{2}$ & 0.92 & $6.7 \times 10^{2}$ & 0.68 & 3. $4 \times 10^{2}$ & 0.66 \\
\hline $\mathrm{C}_{2} \mathrm{H}_{5}$ & $1.1 \times 10^{2}$ & 1. 40 & 5. $4 \times 10^{2}$ & 1.09 & $2.9 \times 10^{2}$ & 0.93 \\
\hline$i-\mathrm{C}_{3} \mathrm{H}_{7}$ & 6. $7 \times 10$ & 2. 35 & 3. $7 \times 10^{2}$ & 1.52 & 1. $8 \times 10^{2}$ & 1. 49 \\
\hline$t-\mathrm{C}_{4} \mathrm{H}_{9}$ & 4. $8 \times 10$ & 20.99 & 2. $6 \times 10$ & 1.82 & 8. $8 \times 10$ & 3. 54 \\
\hline $\mathrm{H}$ & 1 & - & 1 & - & $i$ & - \\
\hline $\mathrm{F}$ & $6.1 \times 10^{-1}$ & 20.35 & $5.2 \times 10^{-1}$ & 8.78 & $7.4 \times 10^{-1}$ & 8. 81 \\
\hline $\mathrm{Cl}$ & 1. $1 \times 10^{-1}$ & 4. 16 & 1. $4 \times 10^{-1}$ & 1.90 & $1.0 \times 10^{-1}$ & 2.09 \\
\hline $\mathrm{Br}$ & $7.5 \times 10^{-2}$ & 3. 61 & $1.0 \times 10^{-1}$ & 1.69 & 7. $2 \times 10^{-2}$ & 1. 85 \\
\hline
\end{tabular}

a) The relative rates $\left(k_{\mathrm{rel}}\right)$ were obtained from the competitive chlorination of substrates and benzene.

b) The plo ratios listed in this Table were found in the competitive chlorination.

c) Ref. 21 .

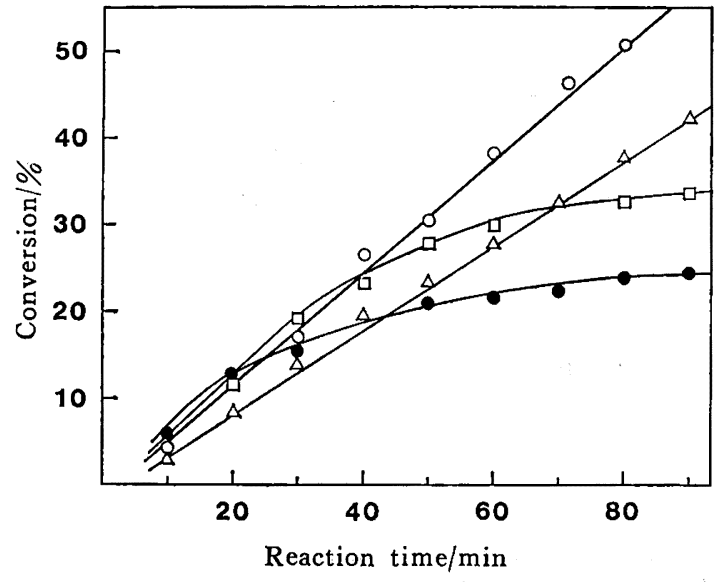

Fig. 1 Silica gel-catalyzed chlorination of cumene at $30^{\circ} \mathrm{C}$

Cumene $1 \mathrm{~mol}$, catalyst $1 \mathrm{~g}$, flow rate of $\mathrm{Cl}_{2}$ $1 \mathrm{~mol} / \mathrm{h}$

$\mathrm{O}: \mathrm{SIL}-11, \triangle:$ SIL-9, $\square: \mathrm{SIL}-1, \mathrm{O}: \mathrm{SiO}_{2}$ (unmodified)

では，位置選択性におよぼす塩案導入速度，および触媒の量によ る影響が大きく，触媒活性の経時変化も大きい。

炭素数 8 のアルキル鎖を固定化した SIL-1 では，活性の低下 はややゆるやかであったが，これも最後にはほとんど失活し，無 修飾シリカゲルとほぼ同様な挙動を示した。一方, ジニトロベン
ズアミド基，ジニトロベン゙ンスルホンフミド基を固定化した SIL-11，および SIL-9 は，無修飾シリカゲルにくらへて, 反応初 期に拈ける活性はやや少ったが，活性はほとんど低下しなかっ た。また，位置選択性の経時変化もきわめて小さかった。

トルエンを基質として検討した結果を表 5 に示す。さきにも述 べたように, 四塩化炭素を溶媒とする系より p/o 比が低く, 少量 の側鎖塩素化物，および多塩素化物の生成が認められた。回収し た修飾シリカゲル触媒は, 再使用した場合にも活性, 選択性には 汪とんど変化はなく，無修飾シリカゲルと大きな違いがある。

\section{7 修飾シリカゲルによる触媒作用の発現}

修飾シリカゲル触媒による塩素化では, シリカゲル表面に残存 するヒドロキシル基により塩素分子が活性化され, 一方, パラ位 選択性の発現に修飾基が関与するるのと考えられる。

適当な構造を有する化合物が，シリカゲル表面に化学的に結合 せずに吸着されているだけで，バラ位選択性が発現されるのかど らかを検討した。ここでは, 選択性の優れた SIL-11 の修飾基と 類似の構造をるつ $N$-プロピル-3,5-ジニトロベンズアミドを, シ リカゲル表面に吸着させて用いた。

このアミドは炭化水素溶媒に難溶性で, 反応中にシリカゲル表 面から溶出しないにもかかわらず，まったくパラ位選択性を示さ なかった。この理由として, シリカゲル表面における存在状態の 迲いが考えられる。たとえば，このアミドは微結晶となって，シ リカゲル表面に付着しており, 修飾基が有効に作用するために は, 分子レベルで均一に存在する必要があるのではないかと思わ れる。

Table 5 Silica gel-catalyzed chlorination of toluene $\mathrm{e}^{\mathrm{a})}$

\begin{tabular}{lccccc}
\multicolumn{1}{c}{ Silica gel } & Time/min & Conv. $/ \%$ & $p / o$ & $\mathrm{BC} / \%^{b)}$ & $\mathrm{DCT} / \%^{\mathrm{c})}$ \\
\hline $\mathrm{SiO}_{2}$ (unmodified) & 60 & 23.4 & 0.70 & 0.86 & 0.46 \\
$\mathrm{SIL}-11$ & 90 & 68.0 & 0.96 & 1.2 & 1.1 \\
$\mathrm{SIL}-11$ (reuse) & 90 & 65.6 & 1.00 & 2.1 & 1.4 \\
$\mathrm{SIL}-11$ (reuse twice) & 90 & 65.9 & 1.02 & 2.5 & 1.6 \\
$\mathrm{SIL}-17$ & 60 & 42.9 & 0.92 & 0.26 & 0.29
\end{tabular}
a) Toluene $1 \mathrm{~mol}$, catalyst $1 \mathrm{~g}$, flow rate of $\mathrm{Cl}_{2} 1 \mathrm{~mol} / \mathrm{h}, 30^{\circ} \mathrm{C}$.
b) Benzyl chloride.
c) Dichlorotoluenes. 
政シリカゲルの表面状態についての候接的な知見は得られて

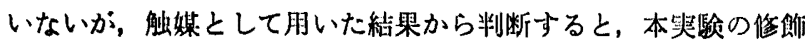
方法により，シリカゲル表面は比校的均一に，策分子㥜状に近い 状热でおおわれているものと推测される。

著者らは本実験に着手するさいに，作業仮说として，修飾基が

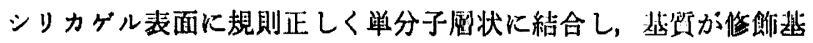
と雪荷移标錯体を形成し，基频分子の向きが制御されると仮定し た 12)。この結果, シリカゲル表面に存在する求㝵子陚薬との反応

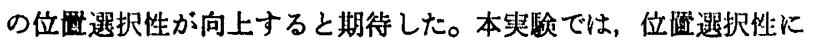
およぼす溶媒効果から觧電的な相互作用が大きいことが明らかに なったか，上述のとおり修飾基の情造と位障選択性の相関を求め ることはできなかった。

位圈選択性の向上は，反応堨の極性の変化の影警がもっとも大 きいと思われる。すなわち、フセトニトリルやニトロメタンなど

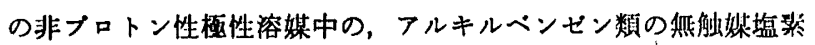
化反応で满いパ位選択性が報告されている201。この理由とし て, 溶媒和したかさ高い求電子峨の存在が教えられている。本塩 柴化反応は，シリカゲル表面を反応场とするすのであるが，ここ にはアミド基やニト口基などの極性の夜い官能基が多数存在し，

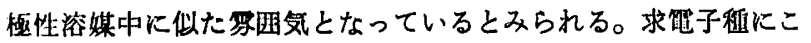
れらの官能基が配位し，選択性の向上に符与するのであろう。ぬ た，基䁈と修飾基との能何移功型鍇体の形成に上る立体的な要因

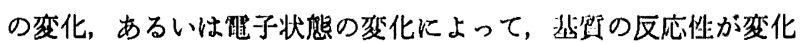
し，パラ位逝択的な塩䋕化が起こるものと考えられる。

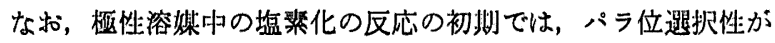

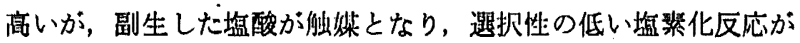
主反応となり，パラ位選択性が急湤に低下する。これに対して修

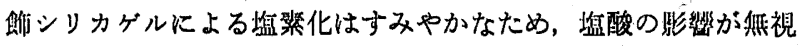
でき， p/0 比の経眭変化が認められないのであろら。

\section{4 結 論}

本吥究で得られた知見はつぎのと拈りである。シリカゲルを蚛 媒に用いるアルキルベンゼン類の塩絭に上る核塩䋕化反応は，シ リカゲル表面を反応場として進行する。シリカゲル裴面に，邂当

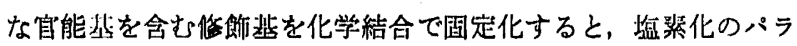
位溉択性が向上する。修飾シリカゲルによる位随選択性の発現に

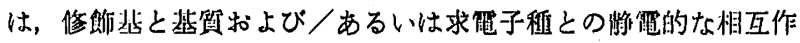
俩が重要な役踣を果している。修飾基は，反応畦であるシリカゲ ル㳖面に間定化された非プロトン性溶媒と見なされる。

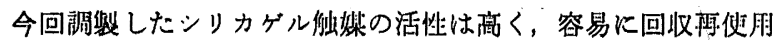

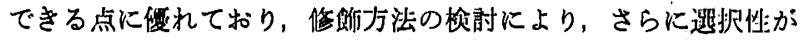
向上できれば，臾用的に有用な例媒となることが期待される。

本研妴を行ならにめたってイハラケミカル株式会社から程々の 嗳助をいたたいた。ここに眍して深く感䀧の恋を丧する。

\title{
Chlorination of Alkylbenzenes Catalyzed by Chemically-modified Silica Gels
}

\author{
Hisatoshi Konishi, Yuji Ichirashi, Masaaki Imal, Tamon Okano \\ and Jitsuo $\mathrm{K}_{\mathrm{IJI}}$ \\ Department of Environmental Chemistry and Technology, Faculty of Engineering, \\ Tottori University ; Koyama-minami, Tottori-shi 680 Japan
}

The para-selective chlorination of alkylbenzenes has been investigated by using chemicallymodified silica gel catalysts. The catalysts listed in Table 1 were prepared by anchoring reactions as shown in Scheme 1. The effect of the type of the anchoring group on the p/o ratio of chlorination of cumene was examined in carbon tetrachloride. The catalysts having dinitrobenzamide moiety showed high para-selectivity. Thus, SIL-17 and -18 gave the $p / o$ values of 4.38 and 4.82, respectively, whereas unmodified silica gel gave the value of 1.16. The solvent effect on the $p / o$ ratio suggested that the electrostatic interaction between the anchoring group and substrate and/or electrophile plays an important role for improvement of the para-selectivity. The activation of chlorine and the chlorination occur on the silica gel surface. The product distribution and the results of the competitive chlorination of alkyl- and halobenzenes with benzene showed the chlorination to be a typical electrophilic aromatic substitution. The chlorination of cumene and toluene without solvent was also examined. The catalyst, SIL-11, had good durability, and could be easily recovered by decantation for reuse. 